DOI https://doi.org/10.30525/978-9934-588-92-1-57

\title{
СУБ'ЄКТ ПРАВА У ЗАГАЛЬНІЙ ПРАВОВІЙ СИСТЕМІ УКРАЇНИ: ТЕОРЕТИЧНИЙ ВИМІР
}

\author{
Калюжна С. B. \\ аспірантка кафедри адміністративного та інформаційного права, \\ стариий викладач кафедри міжнародних відносин \\ Сумського національного аграрного університету \\ м. Суми, Україна
}

Розвиток інформаційного права потребує розбудови різних інститутів інформаційного права, у тому числі інституту суб'єктів цієї галузі права. У межах даної роботи вважалося за необхідне акцентувати увагу на становленні одного із суб'єктів зазначеного інституту, а саме, органів місцевого самоврядування України. На нашу думку, дослідженню названих органів, як суб'єктів інформаційного права, сприятиме формування моделі узагальнених юридичних знань щодо суб'єктів права.

Як і у попередніх дослідженнях у межах наукової школи 3 інформаційного права, наприклад [1,c. 43], вважаємо за доцільне конструктивно використати окремі положення концепції розвитку науки інформаційного права в умовах формування суспільства знання в Україні [2]. Отже, генерування нових юридичних знань науки «інформаційне право», зокрема, нових юридичних знань щодо суб'єктів інформаційного права, має використовувати існуючі юридичні знання загальної теорії держави і права щодо суб'єктів права та їх правового статусу, узагальнюючи результати наукових пошуків у зазначеній сфері знань. У роботі пропонується системне розуміння моделі узагальнених юридичних знань щодо суб'єктів права та їх правового статусу. Системоутворюючим чинником постає мета формування моделі якісні наукові знання щодо зазначених теоретико-правових категорій. Висуваємо гіпотезу, що основними структурними елементами моделі узагальнених юридичних знань постають: 1) юридичні знання щодо суб'єктів вправа; 2) юридичні знання щодо правосуб'єктності; 3) юридичні знання щодо правового статусу. Варто підкреслити, що між зазначеними структурними елементами існують зв'язки взаємосприяння, що, зокрема, сприятиме знаходженню співвідношення між наведеними правовими категоріями, а також забезпечить відповідний рівень узагальнення існуючих юридичних знань. Вважаємо за важливе 
переконатися у процесі наукового дослідження у справедливості висунутої гіпотези.

Грунтуючись на результатах доктринальних досліджень провідних вчених - юристів (зокрема, Г.Ф. Шершеневича, Є.М. Трубецького, С.С. Алексєєва, Л.А. Луць, С.І. Архіпова), переконалися у існуванні трьох історичних етапів щодо змісту поняття «суб'єкт права». Зясовано, що поняття «суб'єкт права» на першому етапі у юридичних джерелах або майже ототожнювалося з поняттям «носій суб'єктивних прав» (Г.Ф. Шершеневич [3, с. 620]), або змістом поняття «суб'єкт права» вважалася його правоздатність (наприклад, Е.Н. Трубецький [4, с. 134]). На другому етапі розвитку теорії «суб’єкта права» деякими авторами пропонується виділяти його основні, ключові риси, наприклад, правосуб'єктність (якість або властивість особи бути суб'єктом права) - С.С. Алексєєв [5, с. 145-146].

Вважаємо за доцільне зазначити, що грунтовніше з'ясувати місце та роль суб'єктів права дозволяє дослідження Л. А. Луць щодо правової системи суспільства [6]. Так, авторка пропонує виділяти три складові у правовій системі: 1) інституційна; 2) функціональна; 3) нормативна [6, с. 17]. Для нашої роботи важливо, що саме суб'єкти права (вочевидь, і суб'єкти інформаційного права також) складають інституційну складову правової системи. Таким чином, ми визначили місце суб'єкта права у загальній правовій системі - це іiі інституційна складова. У свою чергу, функціональна складова правової системи - це зв'язки між суб'єктами права [6, с. 17] (зокрема, суб'єктами інформаційного права). Водночас, аналізучи правову природу цих зв'язків, вчена доходить висновку, що вказані функціональні зв'язки - це соціальні відносини, які (у процесі правового регулювання) перетворюються на правовідносини. Грунтуючись на підході Л.А. Луць, отримано висновок, що органи місцевого самоврядування, як суб'єкти інформаційного права, знаходяться у зв'язках між собою у формі інформаційних правовідносин.

У роботі поділяється існуюча позиція багатьох вчених, що уточнення визначення змісту поняття «суб’єкт права» потребує з'ясування змісту іншого поняття - «правосуб'єктність» Проведений аналіз наукової літератури дозволяє дійти висновку, що здебільшого різниця у наукових позиціях полягає у визначенні змісту та обсягу поняття «правосуб'єктність» (у контексті його співвідношення 3 такими поняттями як правоздатність, дієздатність, деліктоздатність, правовий статус тощо). До речі, досліджуючи зміст інформаційної правосуб' єктності, І.В. Арістова та М.Ю. Кузнецова зазначають, що саме вона $\epsilon$ «необхідною умовою, властивістю, яка допомагає особі 
набути статусу «суб’єкт інформаційного права»« [7, с. 222]. Порівняльна характеристика підходів різних вчених дозволила встановити, що структура правосуб'єктності, а отже, i інформаціної правосуб'єктності складається із трьох частин - інформаційна правоздатність, дієздатність, деліктоздатність.

Вважаємо за доцільне підкреслити, що яскравим представником сучасного етапу розвитку теорії суб'єктів права $\epsilon$ C.I. Архіпов. Цікавими, на наш погляд, є аргументи C.I. Архіпова, який пропонує при визначенні поняття «правосуб'єктність» враховувати, що це «стан приналежності правовій системі, присутності в ній у якості повноправного учасника, можливості користуватися ресурсами даної системи, отримувати від неї захист» [8, с. 203]. Серед іншого, автор вказує на те, що саме «сукупність умов, встановлюваних законодавцем для потенційних суб'єктів права, - це свого роду «правові ворота» в діючу правову систему» [8, с. 204]. Саме тому процес проходження будь-якої «особи» через вказані автором «правові ворота» й перетворюють цю особу на «суб'єкта права», що, у свою чергу, відразу «об'єднує його з усією системою правопорядку, з іншими суб'єктами права» [8, с. 204]. На нашу думку, аргументи C.I. Архіпова щодо розуміння змісту поняття «правосуб'єктність», як правового звязку суб'єкта з правовою системою, заслуговують на підтримку. Вважаємо, що врахування позицій Л.А. Луць та С.I. Архіпова дозволяє стверджувати, що правовий зв'язок між суб'єктами права у статичному стані - це і є «правосуб'єктність» (у тому числі, інформаційна); у динамічному стані - це вже правовідносини (зокрема, інформаційні).

3 нашої точки зору, більш чіткому усвідомленню змісту поняття «правосуб' єктність» сприяє порівняння його змісту з поняттям «суб'єкт права». У роботі підтримується комплексний підхід С.І. Аріхпова, який дозволяє визначити правосуб'єктність як «сукупність юридичних якостей, яка дає змогу особі стати суб'єктом права, тобто, як юридична властивість особи, суспільно-юридичний стан, «який за своєю природою невід'ємний від особи» [8, с. 203]. Водночас нами поділяється відповідний висновок І.В. Арістової та М.Ю. Кузнецової (за аналогією), що інформаційна правосуб'єктність визначає інформаційно-правовий статус особи [7, с. 63].

Відповідно до концепції формування моделі узагальнених юридичних знань щодо суб'єктів права, з'ясовано особливості та співвідношення таких понять як «суб'єкт права» та «суб'єкт правовідносин» (також «учасник правовідносин»). Так, проведений аналіз свідчить, що сутнісна різниця між даними поняттями полягає у потенційній можливості брати участь у правовідносинах («суб'єкт 236 
права») та реальній участі у конкретних правовідносинах («суб'єкт правовідносин»). Узагальнюючи результати існуючих наукових досліджень щодо розуміння поняття «правовий статус», отримано висновок щодо визначення цього поняття. Це - певна система прав, свобод, законних інтересів та обов'язків суб'єкта права, яка визначає місце суб'єкта права у правовій системі. Виходячи із цього, цілком обгрунтованою постає пропозиція І.В. Арістової та М.Ю. Кузнецової щодо визначення поняття «інформаційно-правовий статус»: розглядати його «як комплексне поняття, певну систему, що включає до свого складу інформаційні права та свободи, законні інформаційні інтереси та інформаційні обов'язки суб'єкта інформаційного права» [7, с. 66].

Таким чином, визначено узагальнені юридичні знання щодо трьох складових системної моделі. Важливо, що обгрунтовано існування зв'язків між зазначеними складовими. Тобто, встановлено справедливість висунутої гіпотези.

\section{Література:}

1. Арістова I. В., Стадник Р. І. Органи виконавчої влади України як розпорядники публічної інформації: теоретико-правові та практичні питання: монографія / За заг. ред. І. В. Арістової. К., Видавничий центр НУБіП України 2018. 233 с.

2. Арістова I. В. Наука «інформаційне право» на новому етапі розвитку інформаційного суспільства. Правова інформатика. 2011. № 1. С. 3-11.

3. Шершеневич Г. Ф. Общая теория права. М. : Издание Бр. Башмаковых, 1912. Вып. 2. 805 с.

4. Трубецкой Е. Н. Энциклопедия права. СПб. : Изд-во «Лань», 1998. $224 \mathrm{c}$.

5. Алексеев С. С. Общая теория права в 2-х т. Т. 2. М. : Юридическая литература, $1982.709 \mathrm{c}$.

6. Луць Л. А. Європейські міждержавні правові системи та проблеми інтеграції з ними правової системи України (теоретичні аспекти): монографія. К.: Ін-т держави і права ім. В. М. Корецького НАН України. 2003. 304 с.

7. Арістова I. В., Кузнецова М. Ю. Реалізація інформаційноправового статусу органів виконавчої влади України в інформаційних правовідносинах: монографія / За заг. ред. І. В. Арістової. К.: Видавничий центр НУБіП України, 2015. 250 с.

8. Архипов С. И. Субъект права: Теоретическое исследование. М. : изд-во Р. Асланова «Юридический центр Пресс», 2004. 469 с. 